\title{
Springsteen as Developmental Therapist: An Autoethnography
}

\author{
Rodney Dieser \\ University of Northern Iowa
}

\begin{abstract}
Based on differing theories of moral development proposed by Lawrence Kohlberg, Martin Hoffman, and John Gibbs, this paper posits that listening to Bruce Springsteen's music can increase moral growth. Scores of Springsteen songs parallel psychological techniques used to increase moral development, such as being exposed to two or more beliefs that are contradictory, social perspective-taking by listening to moral dilemmas, gaining empathy with the distress that another person experiences, hypothetical contemplation, and meta-ethical reflection. Through qualitative-based autoethnographical storytelling, the author outlines how his moral development was enabled through such Springsteen songs as "Factory," "Highway Patrolman," "Independence Day," “Johnny 99," and "Used Cars," as well as two self-disclosures from Springsteen's Live 1975-85 album.
\end{abstract}

Since the mid-1980s, Bruce Springsteen has outlined in his interviews that a prominent purpose of his music is to create a space for reflection which he hopes will foster compassion, empathy, understanding, and care on a societal and individual level. In a 2010 interview, for example, Springsteen told NBC's Brian Williams that at its core his music should be "thoughtprovoking" and "make you recognize yourself and recognize the world around you." 1 This theme of "thought-provoking" music

Copyright $(\odot$ Rodney Dieser, 2014. The author would like to thank the reviewers and editors for their outstanding assistance and work in developing this manuscript. Please address correspondence to rodney.dieser@uni.edu.

${ }^{1}$ Brian Williams, "TV Interview," October 7, 2010 in Springsteen on Springsteen: Interviews, Speeches, and Encounters, ed. Jeff Burger (Chicago: Chicago Review Press, 2013), 360.

BOSS: The Biannual Online-Journal of Springsteen Studies 1.1 (2014) http://boss.mcgill.ca/ 
had also arisen in an interview with David Corn in 1996 when Springsteen responded to a question regarding political issues in his music:

I never start with a political point of view ... My memory is of my father trying to find work, what that does to you, and how that affects your image of your manhood, as a provider. The loss of that role is devastating. I write coming from that spot - the spot of disaffection, of loners, outsiders. But no outlaws. It's about people trying to find their way in, but somebody won't let them in. Or they can't find their way in. And what are the actions that leads to? That pretty much obsesses me to this day - and probably will the rest of my life ... I don't set out to make a point, I set out to create understanding and compassion and present something that feels like the world. I set out to make sure something is revealed at the end of the song, some knowledge gained. ${ }^{2}$

In a 1984 interview about Nebraska, Springsteen focused on the idea of empathy; discussing "Johnny 99," a song that outlines how social factors like unemployment contribute to crime, he remarked, "[the song] needed that really kinda austere, echoey sound, just one guitar-one guy telling his story ... like you were just meeting different people, and they just told you what had happened to them, or what was happening to them. So, you kinda walked for a little bit in somebody's else's shoes." 3 Furthermore, in the keynote address Springsteen delivered at the South by Southwest Music Festival in Austin, Texas in March 2012, he underscored how many of his songs, and the music that influenced him, offered opportunities for

\footnotetext{
2 David Corn, "Bruce Springsteen Tells the Story of the Secret America," from Mother Jones (March/April 1996) in Springsteen on Springsteen, 214-215.

${ }^{3}$ Italics not in the original; Roger Scott and Patrick Humphries, "American Heartbeat" from Hot Press (November 1984) in Springsteen on Springsteen, 145.
}

BOSS: The Biannual Online-Journal of Springsteen Studies 1.1 (2014) 
reflection, and, in the process, the opportunity to broaden the listener's sense of empathy. ${ }^{4}$

The purpose of this autoethnography is to use the example of my upbringing to underscore how listening to Springsteen's music assisted my moral development. ${ }^{5}$ As an adolescent in a lower-class family with an illiterate mother battling cancer and close-to illiterate father who was emotionally detached, I did not realize at the time how much Springsteen's music mattered to my moral growth. ${ }^{6}$ All I knew as an adolescent was that I loved his music because I felt a deep connection to it. Clifford Geertz's claim that small facts - such as listening to Springsteen's music - speak to larger issues-the process of moral development-is an ontological and epistemological assumption that lies at the

4 "Bruce Springsteen's SXSW 2012 Keynote Speech," NPR.org, March 18, 2012, Austin, Texas; accessed June 2014, http:// www.npr.org/2012/03/16/148778665/bruce-springsteens-sxsw-2012keynote-speech.

${ }^{5}$ Much of the school structure, environment, and school experiences detailed below appeared in another autoethnography I published in 2008 regarding the ecology of schooling. However, nothing is mentioned about moral development, and scant attention is dedicated to Bruce Springsteen, in the previous study. The only overlap in these two autoethnographies pertains to my school environment as these same school experiences provide the framework for explaining how to improve the ecology of school (in the 2008 article) and how Springsteen's music fostered moral development in this manuscript. Although the names of the schools and teachers have been changed in order to maintain confidentiality, I use the same changed names and schools in both studies. See Rodney Dieser, "Tales from Grade 1 Through 12: Understanding the Complex Web of Multiple Life Forces Located in Schools," Alberta Journal of Educational Research 54 (Fall, 2008): 293-308.

6 The primary reason my parents were illiterate is that both were European immigrants to Canada and learned English as a second language. Secondary reasons rest with poverty and the lack of educational resources.

BOSS: The Biannual Online-Journal of Springsteen Studies 1.1 (2014) 
foundation of this paper. ${ }^{7}$ This autoethnographical study is told with two different, yet coinciding, voices: my present-day academic perspective drawing from theories of moral and ego development as well as my adolescent thoughts of long ago. ${ }^{8}$

\section{Related Literature: Autoethnography}

Autoethnography is a qualitative methodology linked to ethnographical research and narrative inquiry that results in highly personalized narratives of the researcher's engagement with specific sociocultural contexts in the pursuit of knowing more about a phenomenon. ${ }^{9}$ Autoethnography, Stacey Jones writes, involves "setting a scene, telling a story, weaving intricate connections among life and art, experience and theory, evocation and explanation ... hoping for readers who will bring the same

7 Clifford, Geertz, The Interpretation of Culture: Selected Essays (New York: Basic Books, 1973).

${ }^{8}$ Readers are to be mindful that my long-ago adolescent voice is represented as just that - what I believe I thought like as an adolescent located somewhere in the developmental transition between immature and mature moral development. As such, parts of this autoethnography are purposefully written from an adolescent-based superficial thinking perspective that is then blended into an academic voice.

9 To understand the overlap and distinction of autoethnography and narrative inquiry, see Sheila Traher, "Beyond the Story Itself: Narrative Inquiry and Autoethnography in Intercultural Research in Higher Education," Forum Qualitative Sozialforschung/Forum: Qualitative Social Research, 10:1 (2009). In short, the overlap occurs in the storytelling aspects of research. In autoethnography, the author tells a personal story of his or her experience that describes a culture (family or school, for example) in the pursuit of understanding more about a phenomenon. Narrative inquiry is focused on collecting stories as data for understanding other people; Tami Spry, "Performative Autoethnography: Critical Embodiments and Possibilities" in Collecting and Interpreting Qualitative Materials, eds. Norman K. Denzin and Yvonna S. Lincoln (Los Angeles: Sage Publications, 2013), 213-244.

BOSS: The Biannual Online-Journal of Springsteen Studies 1.1 (2014) 
careful attention to your words in the context of their own lives."10 That is, authoethnography uses academic theorization in storytelling to unpack or make sense of past personal experiences linked to understanding specific phenomenon. Although autoethnography can produce fragmented writing that parallels real-life experience, its greatest strength lies in bringing clarity to how academic theories and concepts function in real-world experiences, such as how listening to Springsteen's music can foster moral development. ${ }^{11}$ A well-constructed autoethnographical study should develop emotional involvement which moves the reader to deal with or reflect on similarly complex moral and ethical issues. ${ }^{12}$ In this kind of writing, emotional intelligence is equally as important as academic analysis.

Autoethnography has been employed in diverse academic settings such as gaining insights into female high-performance sport; understanding the lives of Jewish Holocaust survivors; exploring the male experience of having a stillborn baby; outlining the relationship between deep emotion and masculine identity in male barbershop quartets; and highlighting the complexities of

\footnotetext{
${ }^{10}$ Stacy Jones, "Autoethnography: Making the Personal Political" in Collecting and Interpreting Qualitative Materials, eds. Norman K. Denzin and Yvonna S. Lincoln (Thousand Oaks: Sage Publications, 2008), 208.

${ }^{11}$ Carol Ellis, The Ethnographic I: A Methodological Novel About Autoethnography (Walnut Creek: AltaMira Press, 2004); Rodney Dieser, "Qualitative Research," in Conducting and Reading Research in Health and Human Performance, ed. Ted A. Baumgartner and Larry D. Hensley (Boston: McGraw-Hill, 2006), 199-219.

12 Carol Ellis and Arthur Bochner, "Authoethnography, Personal Narrative, Reflexivity: Researcher as Subject," in Collecting and Interpreting Qualitative Materials, eds. Norman K. Denzin and Yvonna S. Lincoln (Thousand Oaks: Sage Publications, 2003), 199-258.
}

BOSS: The Biannual Online-Journal of Springsteen Studies 1.1 (2014) 
gender, family, and race in examining a childhood experience of a family trip to Yellowstone National Park. ${ }^{13}$

\section{Related Literature: Moral and Ego Development}

Moral development is the emergence and understanding of morality that changes over one's lifespan (infancy through late adulthood). Morality is defined as an interplay between what is "right" (justice, reciprocity, equality) and what is "good" (welfare, beneficences, empathy). As explained in the theories of Lawrence Kohlberg, Martin Hoffman, and John Gibbs, moral development has three basic stages. ${ }^{14}$ First, in the immature or superficial stage, morality is based on momentary egocentric desires. Further,

${ }^{13}$ Tosha Tsang, "Let Me Tell You a Story: A Narrative Exploration of Identity in High-Performance Sport," Sociology of Sports Journal, 17:1 (2000): 44-59; Sarah Carney, "Transcendent Stories and Counter Narratives in Holocaust Survivors Life Histories: Searching for Meaning in Video-Testimony Archives," in Narrative Analysis: Studying the Development on Individuals in Society, ed. Colette Daiute and Cynthia Lightfoot (Thousand Oaks: Sage Publications, 2004), 201-222; Marcus Weaver-Highwater, "Waltzing Matilda: An Autoethnography of a Father's Stillbirth," Journal of Contemporary Ethnography, 41:4 (August 2012): 462491; Jeffery Nash, "Ringing the Chord: Sentimentality and Nostalgia Among Male Singers." Journal of Contemporary Ethnography, 41:5 (October 2012): 581-606; Norman Denzin, Searching for Yellowstone: Race, Gender, Family, and Memory in the Postmodern West (Walnut Creek: Left Coast Press, 2008).

14 Regarding moral development, see Martin Hoffman, Empathy and Moral Development: Implications for Caring and Justice (Cambridge: Cambridge University Press, 2000); Martin Hoffman, "Empathy and Prosocial Behavior," in Handbook of Emotions, eds. Michael Lewis, Jeannette M. Haviland-Jones and Lisa F. Bartlett (New York: The Guildford Press, 2008); Lawrence Kohlberg, Essays on Moral Development: The Philosophy of Moral Development Vol. 1 (San Francisco: Harper \& Row 1981); Lawrence Kohlberg, Essays on Moral Development: The Psychology of Moral Development Vol. 2 (San Francisco: Harper \& Row, 1984); John Gibbs, Moral Development and Reality: Beyond the Theories of Kohlberg, Hoffman, and Haidt (New York: Oxford University Press, 2014).

BOSS: The Biannual Online-Journal of Springsteen Studies 1.1 (2014) 
morality follows a rigid conformity to society's rules, where a person internalizes a law-and-order mentality and does not challenge or question social authority. In the second mature or profound stage, morality is based on reciprocity, mutual trust, and intimacy as the basis for a care ethic and interpersonal relationships. The role of social systems and context related to moral judgment begins to grow and the person gains empathy and social-perspective-taking skills. The third existential stage regards morality as an ethic of interconnectedness across humanity resulting in a deep commitment to a moral life. The principle of justice requires that the claims of all people be treated in an impartial manner, respecting the basic dignity of all people.

Of particular importance to mature moral development are empathy and social perspective-taking. Empathy is the ability to understand a person from his or her frame of reference rather than one's own and is an attempt to think within, rather than for or about, the person. ${ }^{15}$ According to Frans de Waal, in empathy we "connect to and understand others and make their situation our own." 16 As a result, empathy can produce altruistic motivation to care for others. ${ }^{17}$ According to Mark Davis, social perspective-taking means adopting, understanding, or considering another person's life condition: their thoughts, beliefs, attitudes, emotions, desires,

15 Sherry Cormier, Paula S. Nurius, and Cynthia J. Osborn, Interviewing and Change Strategies for Helpers (Belmont, California: Brooks/Cole, 2013).

${ }^{16}$ Frans de Waal, The Age of Empathy: Nature's Lessons for a Kinder Society (New York: Broadway Books, 2009), 225

17 C. Daniel Batson, "The Empathy-Altruism Hypothesis: Issues and Implications," in Empathy: From Bench to Bedside, ed. Jean Decety (Cambridge: MIT Press, 2012), 41-54.

BOSS: The Biannual Online-Journal of Springsteen Studies 1.1 (2014) 
preferences, points of view, goals, and intentions. ${ }^{18}$ In order to take social perspective and gain empathy, it is paramount to imagine another person's position and to be able to re-frame one's thinking. ${ }^{19}$ Reframing requires restructuring perceptions of a difficult situation or behavior with an aim toward searching for differing or useful ways to understand a life circumstance and learning alternative ways to view a problematic situation or other people's life condition. ${ }^{20}$

Scores of Springsteen songs and albums are based on empathy and social perspective-taking. Marc Dolan's thoughts about "American Skin (41 Shots)" provide a good example of how Springsteen uses the moral skills of empathy and social-perspective taking:

Springsteen's song ["American Skin"] begins and ends where any ordinary human being's reaction to the Diallo shooting would, simply repeating 41 shots over and over again, stunned at the sheer number of bullets that had hailed down on the victim in a matter of seconds ... [a] cry of a numbed brain trying to absorb what should be an extraordinary fact ... Springsteen's gift in "American Skin" [is] an extension of the way that he had treated such social problems in the past. He made the larger question in this case more immediate by putting himself inside the head of a participant. He had been doing this for over twenty years ... The genius of this song, however, was that it was simultaneously individual and collective ... One verse views the situation from the perspective of one of the shooters,

\footnotetext{
${ }^{18}$ Mark H. Davis, "A Constituent Approach to the Study of Perspective-Taking," in Other Minds: How Humans Bridge the Divide between Self and Others, eds. Bertram F. Malle and Sarah D. Hodges (New York: Guildford Press, 2005), 44-55. ${ }^{19}$ Gibbs, Moral development and Reality.

${ }^{20}$ Cormier, Nurius, and Osborn, Interviewing and Change Strategies.
}

BOSS: The Biannual Online-Journal of Springsteen Studies 1.1 (2014) 
who instantly knows, despite his training, that he has made a tragic mistake. A second verse adopts the perspective of an African American mother instructing her young son how to act in front of the police. All his life, Springsteen [has] believed in and preached a biracial America. This song, however, [makes] that biracial reality palpable, as a white police officer and a black mother are gathered into the same collective, frightening we ... Springsteen simply utter[s] a basic fact: we are all in this together, baptized in these waters and in each others' blood. ${ }^{21}$

"American Skin (41 Shots)" provides empathetic insights into the behaviors of white police officers and an African-American mother (mature stage of moral development), while outlining an ethic of interconnectedness (existential stage of moral developmental).

Building on moral development theory, Stuart Hauser outlines a four-phase model of adolescent ego development that occurs within the family and school context. ${ }^{22}$ First, the impulsive

21 Emphasis in original; Marc Dolan, Bruce Springsteen and the Promise of Rock'n'Roll (New York: W.W. Norton \& Company, 2012), 357; “American Skin (41 Shots)" is based on the events surrounding the death of 22-year-old West African immigrant Amadou Diallo who worked at a convenience store and lived in the poor section of the Bronx. Just after midnight on February 4, 1999, four New York City plainclothes police officers mistakenly thought Diallo was an armed serial rapist. When Diallo reached for his wallet to show the police his legal identification, the police officers thought he was reaching for a gun, and shot the unarmed Diallo 41 times. For more details, see June Sawyers and Christopher Phillips, Tougher Than the Rest, 100 Best Bruce Springsteen Songs (New York: Omnibus Press, 2006).

22 Stuart Hauser, Adolescents and Their Families: Paths of Ego Development (New York: Free Press, 1991). More recent academic labor related to Hauser's four phase model of adolescent ego development include Stuart Hauser, Joseph Allen, and Eve Golden, Out of the Woods: Tales of Resilient Teens (Cambridge: Harvard University Press, 2008) and Joseph Allen "Experience, Development, and Resilience: The Legacy of Stuart Hauser's Explorations of the Transition from

BOSS: The Biannual Online-Journal of Springsteen Studies 1.1 (2014) 
stage is characterized by an adolescent who cannot control impulses in which behaviors are based on self-gratification. The adolescent is manipulative and the concept of right and wrong is based on external reasons such as avoiding punishment. Within the family and school context, conversations and interactions are marked by distracting remarks wherein parents and teachers ignore or talk around serious issues and often ridicule other people. There is scant or no bi-directional communication, with little empathy, social perspective-taking, curiosity, or patience, along with combative relationships. Second, the conformist stage is characterized by an adolescent who has conventional thoughts with some self-involvement, along with some acknowledgement of other points of view or social perspective-taking. Within the family and school context, conversations and interactions are marked by the expression of feelings, but more as clichés. Parents and teachers often reflect standards of the community, such as unquestioningly following school or community policies. Teenagers show empathy toward parents and siblings but parents and teachers may not be empathetic toward children and students. Parents and teachers usually have little patience for ambiguity and have firm and inflexible rules. Third, the consciousness stage is characterized by an adolescent who has self-evaluating responses and not only accepts criticism, but views criticism as being linked to personal growth. The adolescent will act within an internal and developing value system. Fourth, the autonomous stage is characterized by an adolescent who thinks in complex ways and copes with inner conflict as they are aware of behaviors linked to competing or

Adolescence into Early Adulthood" Research in Human Development, 7:4 (November 2010): 241-256.

BOSS: The Biannual Online-Journal of Springsteen Studies 1.1 (2014) 
differing values. Such adolescents have empathy and understand the concept of interdependence (the need for others) and social perspective-taking. Within the family and school context, and in relation to both the consciousness and autonomous stages, interactions are based on welcoming differences of opinions, rich conversations, and parents or teachers willing to enter into a social perspective-taking dialog and willing to change opinions based on what they hear and learn during a conversation. Families and teachers enjoy conversations and there is a level of communication about communication. Adolescents do not ridicule or demean parents or teachers.

\section{My Social Context of Home and School and Early Connection to Springsteen's Music}

Social context is a paramount factor in the development of morality. In general, families and schools that exhibit immature moral development tend to generate children who are equally superficial as moral thinkers. When I think back on my adolescence from a moral development perspective, I believe my family acted out of a superficial law-and-order mentality marked by rigid conformity to rules. My father was authoritarian and emotionally detached. From an ego development perspective, my family acted from an impulsive stage. Family members did not talk about serious issues and there was no bi-directional communication as well as little empathy, curiosity, or social perspective-taking. My parents dealt with my mother's incurable cancer in an unhealthy and disconnected way - by not talking about it - and my parents asked me to promise to keep this dark secret to myself. Due to my parents' trauma-oriented childhoods (which included war, 
physical abuse, hunger, and extreme poverty/homelessness) they did not have childhood experiences in environments that fostered moral development. Due to the fact that my mother battled cancer for six years and my family struggled financially, my parents did not have the physical or emotional energy, the educational background, or the financial resources that are helpful in fostering moral development. ${ }^{23}$

Likewise, when I look back at the junior and high school system I interacted in, I see the same pattern: an impulsive school environment marked by teachers who had little empathy or patience and classes based on a top-down rote learning and a testbased approach with little bi-directional communication or group processing. Most of the students and teachers at Harry Junior High School (HJHS) and Central High School (CHS) had immature moral development. It was, using the title of a Springsteen song, a "Jungleland" and a prison sentence. Some of the teachers were also bullies. For example, Mr. Alvord, the French teacher, enjoyed bullying students and used intimidation and fear strategies to control his classroom. He would give the strap to students within the classroom as a public spectacle, a practice similar to prison rituals. ${ }^{24}$ He would occasionally grab male students by the neck

${ }^{23}$ My parents never enrolled any of their children into any type of youth or community programs, whether educational, recreational, musical, writing, sports, or nature-based. They simply did not have any extra money. Survival issues are a principal obstacle to both critical and moral thinking; see Wanda Teays, Second Thoughts: Critical Thinking for a Diverse Society (Boston: McGrawHill, 2010).

24 See Michel Foucault, Discipline and Punishment: The Birth of the Prison (New York: Vintage Books, 1977) and James, Marshall, "Foucault and Education," Australian Journal of Education, 33:2 (1989): 99-113 regarding how school and

BOSS: The Biannual Online-Journal of Springsteen Studies 1.1 (2014) 
and ram them against the cement wall while holding them up by their neck so that their feet would dangle in the air. Another teacher, Mr. Mitchell, killed himself with a gun. After his suicide, I always felt strange and uncomfortable when I was in his classroom, and the fear of death was real to me, as I feared my mother's death.

In regard to the actual day-to-day life of my junior high school, group-gender bullying proved widespread. In keeping with hegemonic masculine norms, boys were expected to be aggressive, competitive, and to have identities related to physical strength and sport and to view girls as sexual objects. ${ }^{25}$ Boys would "gang-bang" girls in the classroom or hallways by reaching down their pants or inside their blouses and the ubiquitous physical intimidation, profanity, harassment, and name-calling was widespread throughout the junior high school community. Teachers were intellectually dead and emotionally lifeless; they seemed to be in the classroom just to collect a paycheck. There was no care-ethic (a sign of possible profound moral development), and teachers themselves seemed to be located in the immature stages of moral and ego development due to their propensity for role obligations, rigid conformity to rules, stereotypical conceptions of good people, and, perhaps most widespread, an internalized lawand-order mentality. My reflection on HJHS aligns with Kohlberg's and Higgins's thoughts that too many American schools are based

prison settings have great overlap. To learn more about the prison-like systems of HJHS and CHS see Dieser, "Tales from Grade 1 Through 12."

${ }^{25}$ To learn more about hegemonic masculinity see Michael Messner, "Boyhood, Organized Sports, and the Construction of Masculinities" in Men's Lives eds. Michael S. Kimmel and Michael A. Messner (New York: Macmillan, 1992), 161176.

BOSS: The Biannual Online-Journal of Springsteen Studies 1.1 (2014) 
on immature moral development in school structure, teaching pedagogy, and student self-centeredness. ${ }^{26}$

I understand why I connected to the themes of death, fear, and loneliness in Springsteen's The River album when I was an adolescent. As Rob Kirkpatrick posits, “[a] sense of fear pervades the album. If The River is Springsteen's most playful album, it's also his most depressing. . . . Songs throughout the album ponder the sense of loss when dreams are lost."27 Knowing in junior high that my mother had cancer and eventually in high school that her breast cancer had become a terminal bone cancer presented me with the dichotomy of dreams and reality and caused me to ponder how dreams are lost. For example, the concluding song on The River, "Wreck on the Highway," tells the story of lost dreams via death as the narrator, while driving on a desolate highway in the rain, comes upon a wreck in which the driver asks him for help but eventually dies. The narrator imagines "a girlfriend or a young wife" informed by a state trooper of the death of her loved one in a car wreck. Likewise, "Stolen Car" provides the chilly feeling of emotional isolation. Springsteen sings with only a gentle acoustic guitar and piano accompaniment about a car thief who has sunk into selfdestructive sadness and loneness after the dream of his marriage ends. In the concluding verse, the narrator tries to convince himself that he will "be alright," but he is overwhelmed with the fear that "in this darkness I will disappear." Although not moved by

\footnotetext{
26 Lawrence Kohlberg and Ann Higgins, "School Democracy and Social Interaction," in Moral Development through Social Interaction, eds. William Kurtines and Jacob Gewirtz (New York: John Wiley \& Sons, 1987), 102-128.

27 Rob Kirkpatrick, The Words and Music of Bruce Springsteen (Westport, Connecticut: Praeger, 2007), 74.
}

BOSS: The Biannual Online-Journal of Springsteen Studies 1.1 (2014) 
witnessing a wreck on the highway or being involved in stealing cars, I empathized with the depressive notions in these songs.

During junior high and high school, I began listening to music as a means to cope with the stresses of my life. Although I enjoyed Springsteen's playful songs such as "Out in the Street" and "Sherry Darling," at a deeper level certain Springsteen songs allowed me to reflect and process life's struggles. I identified with the lyrics of the second verse of "Darkness on the Edge of Town" whose narrator claims that "Everybody's got a "secret ... / Something that they just can't face." While some bear the weight of that secret every day, others "cut it loose," releasing themselves from the burdens of the past. I did not relate to the actual events of the song - the narrator's desire to reunite with an ex-lover on the edge of town; rather, I connected to the higher-order feelings of darkness when someone has a secret that they must carry with them. I could only let out the secret of my mother's cancer or think about her death in the privacy of my bedroom listening to Springsteen's songs. In addition, "Darkness on the Edge of Town" was even more relevant to my adolescent mind as our house was literally on the edge of town.

\section{Developing Empathy and Social Perspective Through Springsteen's Songs}

Psychological intervention to increase moral development can include story-telling whereby the reader is exposed to two or more beliefs that are contradictory, is challenged to see things from another person's point of view, or is engaged in problem-solving

BOSS: The Biannual Online-Journal of Springsteen Studies 1.1 (2014) 
moral dilemmas. ${ }^{28}$ Moral dilemmas cause hypothetical contemplation, meta-ethical reflection, empathy, and social perspective-taking. ${ }^{29}$ Moreover, moral dilemmas as interventions will often result in the development of re-framing skills. ${ }^{30}$

My early connection to Springsteen's music helped me cope with life by providing periods of escapism ("Sherry Darling") along with music and stories to help me process death ("Wreck on the Highway") and fear ("Stolen Car"). However, Springsteen's songs and stories - especially from Darkness on the Edge of Town (1978), The River (1980), Nebraska (1982), and Live/1975-1985 (1986) - helped foster my overall moral development by specifically developing hypothetical contemplation, empathetic understanding, and social perspective-taking. Due to the fact that I was not experiencing the family or school environments that foster this type of moral and adolescent development, Springsteen's music was the stimulus for

28 This type of treatment is strongly advocated by Kohlberg and Gibbs. See Kohlberg, Essays on Moral Development, Vol. I and Vol. 2. A contemporary example of treatment to increase moral development is the Equipping Youth to Help One Another (EQUIP). EQUIP specifically helps youth to learn empathy and social perspective taking by reading age-appropriate complex moral stories/dilemmas and leading discussion groups so that youth can learn how to take the perspective of another person, which leads to greater care and compassion. See Ann-Marie DiBiase, John Gibbs, Grandville Bud Potter, and Mathew R. Blount, Teaching Adolescents to Think and Act Responsibly: The EQUIP Approach (Champaign, Illinois: Research Press, 2012) and Gibbs, Moral Development and Reality.

${ }^{29}$ Gibbs, Moral Development and Reality.

30 See Judith Beck, Cognitive Behavioral Therapy: Basics and Beyond (New York: Guilford Press, 2011). For specific treatment of examples of cognitive-based reframing therapy for youth, see DiBiase, et al., Teaching Adolescents and Martin E. P. Seligman, Karen Reivich, Lisa Jaycox, and Jane Gillham, The Optimistic Child: A Proven Program to Safeguard Children Against Depression and Build Lifelong Resilience (Boston: Mariner Books, 2007).

BOSS: The Biannual Online-Journal of Springsteen Studies 1.1 (2014) 
such learning. In regard to Hauser's stages of ego development, Springsteen's music was the vehicle that helped my ego develop from the impulsive stage to the conformist stage and even planted the seeds of the consciousness stage: some degree of value clarification and complexity in thought. In regard to moral development, Springsteen's songs helped me gain a social system perspective, a sign of movement between the immature and mature stages. For example, the song "Johnny 99" presents the narrative of a character, Ralph, who, after he loses his job in an automobile plant, kills a night clerk in a drunken rage. Ralph pleads to the judge that he has "debts no honest man could pay" as he is facing a bank foreclosure on his home. When Ralph is sentenced to 99 years in jail and gains the nickname "Johnny 99," his loved ones protest the verdict while Ralph requests to be executed. Listening to this narrative, and to other songs with similar themes (such as "Atlantic City") helped me realize how social systems and factors such as poverty, hunger, a sluggish economy, unemployment and accompanying feelings of hopelessness, and a lack of community resources can serve as antecedent factors in causing criminal acts. ${ }^{31}$ The moral framework of Nebraska - which aligns to Kohlberg's and Gibbs's profound stage of moral development-underscores the importance of a care-ethic and gaining perspective on what happens to people when they lose any sense of community and

${ }^{31}$ In regard to how social systems/variables can be antecedent factors in the development of crime and juvenile delinquency, see William Barton, "Juvenile Justice Policies and Programs," in Social Policy for Children and Families: A Risk and Resilience Perspective, eds. Jeffrey Jenson and Mark Fraser (Thousand Oaks: Sage Publications, 2011), 306-352; in addition, see William Cockerham, Sociology of Mental Disorder (Boston: Pearson, 2011) regarding how social systems/variables can be antecedent factors in the development of mental illness.

BOSS: The Biannual Online-Journal of Springsteen Studies 1.1 (2014) 
have no one to turn to for help. ${ }^{32}$ Many Springsteen songs present moral dilemmas that cause hypothetical contemplation, metaethical reflection, empathy, and social perspective taking; the same activities that Kohlberg and Gibbs suggest advance moral development.

While listening to these songs as an adolescent, I was gaining the moral developmental skills of empathy and social perspective-taking from Springsteen's characters in these stories. Listening to "Johnny 99," I was exposed to contradictory beliefs and the emotions of the title character and his loved ones, but I also considered the family members of the dead night clerk. In both "Johnny 99" and "Atlantic City" I learned how social factors can propel people toward crime as both main characters had "debts that no honest man can pay" due to unemployment and broader economic problems. While listening to "Used Cars" I thought of the sadness that an entire family must experience when a mother has to sell her wedding ring in order to come up with enough money to purchase a used car. I could also relate to the feelings of povertyinduced shame the boy or young adolescent felt regarding the used car that the neighbors come to ogle.

"Highway Patrolman" also proved formative as it presented me with a further moral dilemma. In this song, Joe, a patrolman, is constantly looking the other way to help his "no good" brother Frankie. The climax of "Highway Patrolman" occurs when Joe has to pursue his fleeing brother after Frankie commits a serious crime (leaving a man for dead after a bar fight) and chases him within five miles of the Canadian border. When he realizes that Frankie intends to flee the country, Joe pulls his patrol car to the side of the

32 Peter Carlin, Bruce (New York: Touchstone, 2012), 297.

BOSS: The Biannual Online-Journal of Springsteen Studies 1.1 (2014) 
road to "watch his taillights disappear." As Joe watches Frank escape, his mind wanders back, and he imagines better times with his brother. While taking a high school psychology/sociology class I learned about Kohlberg's stages of moral development and connected the "Highway Patrolman" narrative to the druggist dilemma that my teacher read to the class, taken directly from Kohlberg's academic labor and research studies. ${ }^{33}$ I wondered if I would let my brother escape if he had killed someone and I was a highway patrolman. I was learning and applying the moral skills of empathetic social perspective-taking through Springsteen's song narratives. ${ }^{34}$

Sometime during my senior year of high school, I began to develop empathy toward my father, and Springsteen's music provided the scaffolding of social-perspective taking. That is, Springsteen's music helped me re-frame my thinking. In particular,

33 The following is the druggist dilemma present by Kohlberg, Essays on Moral Development, Vol. I: "A woman was near death from a special kind of cancer. There was one drug that the doctors thought might save her. It was a form of radium that a druggist in the same town had recently discovered. The drug was expensive to make, but the druggist was charging ten times what the drug cost him to produce. He paid $\$ 200$ for the radium and charged $\$ 2,000$ for a small dose of the drug. The sick woman's husband, Heinz, went to everyone he knew to borrow the money, but he could only get together about $\$ 1,000$, which is half of what it cost. He told the druggist that his wife was dying and asked him to sell it cheaper or let him pay later. But the druggist said, "No, I discovered the drug and I'm going to make money from it." So Heinz got desperate and broke into the man's store to steal the drug for his wife. Should Heinz have broken into the laboratory to steal the drug for his wife? Why or why not?"

34 Replacing "you" statements with "I" statements are more likely to induce empathy because "you" statements often provoke defensive responses (Gibbs, Moral Development and Reality). In "Highway Patrolman" Springsteen uses "I" statements as the song/story is told from the point of view of a State Patrolman named Joe Roberts.

BOSS: The Biannual Online-Journal of Springsteen Studies 1.1 (2014) 
the song "Factory" helped me re-conceptualize how I thought of my father. Told from an adolescent's perspective, "Factory" illuminates how blue-collar labor sucks the life out of his hardworking father: not only does the "working life" debilitate his father's hearing but, at each day's end the "Men walk through [the factory] gates with death in their eyes." When listening to this song, I thought about my own father, how he would come home, dayafter-day, during the long and cold Canadian prairie winters as a construction worker with a mustache literally frozen, take off his work boots and thick wool socks, exposing feet that were bright red from the cold. I began to understand how the social factors that surrounded my father-his lower social class, past childhood traumas due to World War II, emotional strain of watching my mother die a slow and painful death, grueling and abusive work that created "death in his eyes" - contributed to his emotional lifelessness, as Springsteen describes the working men in "Factory." He would come home from work, eat, and disengage by watching TV in a comatose manner.

In addition, and perhaps most importantly to my adolescent mind, two stories that Springsteen shared with the audience from his Live 1975-85 album, along with a conversation with my father's sister, Aunt Rose, caused me to engage in social perspective-taking and re-frame my father's emotionally-detached behaviors and authoritarian parenting style. My aunt shared with me something that no one else ever told me: that my father was affected, as an adolescent, by World War II, and by how his family had been homeless in Europe. Under these circumstances, my father had to be emotionally detached and authoritarian in order to take care of his younger brothers and sisters. I learned that my father 
erroneously believed he was responsible for the death of his brother David when David became separated from the rest of the family as they fled from the Nazis. My father lived with this guilt throughout his life and never talked about it. I also learned that my father was in charge of scouring through garbage cans and would bring home potato peelings so that his mother could boil them in order to make soup. As I grew older and learned more about mental health, I realized that my father's authoritarian disposition and emotional detachment stemmed from the events of his youth, coupled with deadening and physically grueling work, and I wondered if he lived with depression or post-traumatic stress disorder. I also learned why both my mother and father asked me not to tell anyone about my mother's terminal cancer: my parents had learned from the trauma in their lives to hide dark secrets, which is a common, but unhealthy, way to deal with trauma. ${ }^{35}$ Silence is often used to hide shame.

In the middle of a performance of "Growin' Up" featured on Live 1975-85, Springsteen tells a story about his upbringing, of the constant verbal fighting and emotional distance that occurred between his father and himself and of his father's lack of support for Springsteen's passion for playing music. Dolan underscores that in the 1960s, "The one overwhelming, often reiterated event of Bruce's life ... was his never-ending arguments with his father ... Doug and Bruce Springsteen appear to have fought long, loud, and constantly during the late 1960s. The arguments always seemed to start the same way, with the father asking his son 'what did I think I

\footnotetext{
${ }^{35}$ In regard to unhealthy coping with trauma, see Judith Herman, Trauma and Recovery: The Aftermath of Violence-From Domestic Abuse to Political Terror (New York: Basic Books, 1997).
}

BOSS: The Biannual Online-Journal of Springsteen Studies 1.1 (2014) 
was doing with myself.'"36 Bruce Springsteen's family life sounded an awful lot like mine.

Another story serves as the introduction to "The River," wherein Springsteen tells the audience about a more emotionally abusive interaction with his father. In these two confessionals, Springsteen shares how his father repeatedly told him during his adolescent years that he was wasting his life wanting to be involved in music and that the Army would "make a man" out of him. Springsteen further reveals that when he was in a motorcycle accident as a seventeen-year-old, the attorney representing the Springsteen family told Bruce that he should be guilty of causing the accident simply because he looked like a punk with his long hair. His authoritarian father, who sounded like my father, had a barber cut Springsteen's hair against his wishes while he lay in a hospital bed. This incident led to Springsteen shouting that he hated his father and led to him spending as much time away from his home as possible. Later, when Springsteen failed his Army draft medical examination due to the health consequences of the motorcycle accident, he informed his father, who responded affirmingly, "That's good," thus demonstrating how an authoritarian and emotionally-isolated father shows love.

After listening to Springsteen's self-disclosures over and over again, and hearing reflections of my own home life in these two confessionals, I began to gain empathy for my father. ${ }^{37}$ That is

\footnotetext{
36 Dolan, Bruce Springsteen and the Promise of Rock ' $n$ ' Roll, 21.

37 In mental health counseling, a self-disclosure is when a therapist shares personal information about himself/herself to the client in order to help the client share more about their presenting problem. Self-disclosures have many beneficial aspects, such as normalizing problems and developing trust as the
}

BOSS: The Biannual Online-Journal of Springsteen Studies 1.1 (2014) 
to say, I was using Springsteen's self-disclosures as a reflective space so I could apply social perspective-taking and re-frame my thoughts about my father. I connected the latter Springsteen selfdisclosure to experiences with my authoritarian father, who would tell (not ask) me to drink buttermilk with him. Instead of asking me how my life was going and expressing some degree of encouragement, my father would call me into the garage when he took a break from tinkering and have me drink buttermilk in relative silence. I never liked the taste of it, but I drank it because he told me to. However, after we both shared a drink, he gave me a head nod, which, in an emotionally-detached hegemonic masculine manner, was a way of showing me love. After listening to Springsteen talk about re-framing his father's behaviors and seeing signs of love, I began to restructure my father's behaviors and could see glimpses of his love, and began to understand why he was emotionally detached. I began to understand that due to my father's painful life experiences, he was unable to share his love. Although this switch in thinking may seem simplistic, from a youth development perspective, this is a profound cognitive change toward mature moral development. ${ }^{38} \mathrm{I}$ was unknowingly applying cognitive behavioral therapy interventions by challenging and changing my automatic irrational thoughts to reality-based rational thoughts through Springsteen's music. ${ }^{39}$ Although this may sound

client interprets a therapist as a "real human being." See Cormier, Nurius, and Osborn, Interviewing and Change Strategies.

38 See Gibbs, Moral Development and Reality.

39 The basic tenet of personality from a cognitive behavioral therapy point of view is that emotions (or emotional disturbances) are largely the product of irrational thinking or hot thoughts (quick automatic thoughts that enter a person's mind with little supportive evidence). Cognitive therapy helps people identify automatic thoughts to evaluate if such thoughts are reality

BOSS: The Biannual Online-Journal of Springsteen Studies 1.1 (2014) 
corny, when I would hear the lyric from "Mansion on the Hill" about a father and son riding "through the streets of a town so silent and still," I would think about the early morning car rides I shared with my father. During the extreme cold of winter, my father would drive me to school between 6:30-7:00 a.m. ${ }^{40}$ Apart from the custodian, I would be the only other person at the school, and I began to re-frame my automatic thought of hating those early morning rides to school to a nostalgic reflection of driving with my father in silence, similar to the events of this song. As an adolescent, I was romanticizing Springsteen's songs, while changing automatic thoughts, as I sought to develop a better relationship with my father.

\section{Conclusion}

Psychological treatment to increase moral development can include story-telling whereby the reader is exposed to two or more beliefs that are contradictory, a moral dilemma that stretches moral thinking or whereby a person is challenged to see things from another person's point of view. It can also include the cognitivebehavioral approach of re-framing. As I listened to Springsteen's songs as an adolescent, these psychological techniques were being actualized. But instead of a mental health counselor, Springsteen

based/rational (there is solid supportive evidence for a thought). If the automatic thought is deemed irrational, mental health therapists will help a client dispute and replace irrational thoughts with rational thoughts based on the ability to marshal evidence for such thoughts. See Beck, Cognitive Behavioral Therapy.

${ }^{40}$ Most days, before I could drive a car, I would walk the 2.5 kilometers to school. When the temperature was extremely cold, my father would drive me to school, well before school started due to his inability to start work later. My mother never learned to drive.

BOSS: The Biannual Online-Journal of Springsteen Studies 1.1 (2014) 
served as my developmental therapist. I located in his canon "thought-provoking" music that taught me the moral development skills of empathy and social perspective-taking. I applied moral and ego development psychological techniques to the dilemma in "Highway Patrolman" and developed general empathy by listening to songs such as "Johnny 99" and "Used Cars." I learned social perspective-taking skills - specifically toward my fatherthrough Springsteen's self-disclosures from his Live 1975-85 album and from songs such as "Independence Day" and "Factory." Lacking traditional sources to facilitate moral development, I turned to Springsteen's music and stories of his upbringing in order to help me through mine.

BOSS: The Biannual Online-Journal of Springsteen Studies 1.1 (2014) 